The Bulletin of the Dnipropetrovsk university. Series: Management of innovations

Issue 7, Volume 24 (2016)

DOI: $10.15421 / 191621$

Received: 15 Oct 2016

Accepted: 30 Nov 2016

Published: 25 Dec 2016

\title{
Management of innovation in the electricity sector: impact of framework policy
}

The framework policy has a significant impact on the management of innovation in the electricity sector. To be effective, the framework policy should be adapted to the local, national, and international context. In order to find out how to adapt the policy framework efficiently, it is important to carefully examine the existing situation. When considering the development of renewable energy technology for electricity generation, policy framework plays a more important role. A short literature review analysis on the topic reveals that for developing countries having a low electricity access rate, the deployment of mini-grid presents a huge opportunity. In each local context it is important, however, to define which type of mini-grid should be adapted and how to increase the renewable energy share of mini-grid. It is also important to review the different existing policy mechanisms related to mini-grid and renewable energy development and consider how each mechanism can influence innovation in the electricity sector. The current research is dedicated to the framework policy analysis only.

Keywords: mini-grid; framework policy; electricity sector; systems theory; electricity sector management.

JEL Classification 013; 043; 055.
‡Esther Prudence Jouégo, Research associate,

Neu-Ulm University of Applied Sciences, Neu-Ulm, Germany, +4973197621623, Esther-prudence.jouego@hs-neu-ulm.de 


\section{Менеджмент інновацій \\ у галузі електроенергетики: вплив структурної політики}

Е. П. Хуего

Університет прикладних наук, Ной-Ульм, Німеччина

Структурна політика має значний вплив на менеджмент інновацій в секторі електроенергетики. Щоб бути ефективною, структурна політика повинна бути адаптована до місцевих, національних та міжнародних умов. 3 метою визначення, як ефективно провести адаптацію структурної політики, необхідно уважно вивчити ситуацію, що склалася в кожній окремій місцевості. Для розвитку сектора відновлюваної електроенергії структурна політика відіграє навіть ще більш важливу роль. Короткий аналіз літератури по даній темі показав, що країни, що розвиваються, мають низький рівень доступу до електрики, і впровадження мініелектросистем відкриває для них нові можливості. На місцевому рівні в кожному окремому випадку необхідно визначати, який тип мініелектросісітем впроваджувати, а також як збільшити частку відновлюваної енергії, яка подається в мініелектросистему. Також важливо розглянути існуючі структурні механізми, застосовані в області мініелектросистем і розвитку відновлюваної енергетики, звертаючи увагу на те, як кожен з механізмів впливає на інновації в енергетичному секторі. Дане дослідження присвячене аналізу типів структурної політики, що можуть бути застосовані.

Ключові слова: мініелектросистема; структурна політика; сектор електроенергетики; системна теорія; менеджмент енергетичного сектору.

\section{Менеджмент инноваций в сфере электроэнергетики: влияние структурной политики}

Э. П. Хуэго

Университет прикладных наук, Ной-Ульм, Германия

Структурная политика обладает значительным влиянием на менеджмент инноваций в секторе электроэнергетики. Чтобы быть эффективной, структурная политика должна быть адаптирована к местным, национальным и международным условиям. С целью определения, как эффективно провести адаптацию структурной политики, необходимо внимательно изучить сложившуюся ситуацию. Для развития сектора возобновляемой электроэнергии структурная политика играет даже еще более важную роль. Краткий анализ литературы по данной теме показал, что для развивающихся стран, имеющих низкий уровень доступа к электричеству, внедрение миниэлектросистем открывает новые возможности. На местном уровне в каждом отдельном случае необходимо определять, какой тип миниэлектросиситем внедрять, а также как увеличить долю возобновляемой энергии, подаваемой в миниэлектросистему. Также важно рассмотреть существующие структурные механизмы, используемые в области применения миниэлектросистем и развития возобновляемой энергетики, обращая внимание на то, как каждый из механизмов влияет на инновации в энергетическом секторе. Данное исследование посвящено анализу типов применяемой структурной политики.

Ключевые слова: миниэлектросистема; структурная политика; сектор электроэнергетики; системная теория; менеджмент энергетического сектора. 


\section{Introduction}

ini-grids are «one or more local generation units supplying M electricity to domestic, commercial, or institutional 11 consumers over a local distribution grid. They can operate in a standalone mode and can also interconnect with the central grid when available»(Deshmukh et al., 2013). A «Mini-Grid Business» describe thus a small or medium enterprises focusing on the generation and distribution of electricity through a mini-grid. The mini-grids are, however, not a stand-alone objects but firms acting in a complex and dynamic environment. Apart the national and international formal rules, there are many factors which can and do regularly influence the functioning of mini-grid. For example, local authorities are empowered to make formal decisions on local taxes, architectural prescriptions, and others (Peterson, 1981). At the same time there are many informal factors influencing the functioning of mini-grids. Support by local population (Hellpap, 2013), perception of the firm image (Franz et al., 2014), struggles between local and regional or national authorities (Steurer et al., 2016) as well as many other factors represent the variable which should be taken into account when planning a work of a mini-grid.

Research related to mini-grid shows that there are three kind of existing mini-grid:

- public mini-grid: a public mini-grid scheme occurs when the electricity authority of a country decide to establish several mini-grids over the country to supply electricity. This is, for instance, the case of some countries as Kenya, Ghana, Tanzania, ... . Here the mini-grid belongs to the state or to a public entity (Economic Consulting Associates, 2014);

- private mini-grid: private mini-grid occurs when the electricity authority of a country deliver an authorisation to a private company to generate and supply electricity to a specific area. The private company could then decide to set a price for electricity, or the price for electricity can be set by the authority. This structure of mini-grid exist in some countries as in Tanzania for instance (Van Der Plas \& Pigaht, 2013);

- community mini-grid: a community mini-grid occurs when the inhabitants of a locality organize themselves through or without the municipality and establish his own system to generate and supply electricity the related community (Economic Consulting Associates, 2014).

The literature review related to the mini-grid development in SubSaharan African countries shows that without specific policy incentive for green mini-grid, the existing mini-grid are at a rate of almost 90\% using a diesel generator to generate electricity. The only means to change this trend should be to define the right policy intervention for the development of green mini-grid.

\section{Purpose of the study and research limitation}

he aims of this study is to find out which impact the policy T framework and regulatory has on the development of minigrid and how to define an effective mini-grid policy intervention.

The main limitation of the study is that it considers only the framework policy factor, while there are other factors which should influence the development of mini-grid.

\section{Research Question}

he key world for the research of the literature review was: $\langle$ T «literature review mini-grid». The aims of this literature review was to find out what has already be done regarding the topic. Since this work has a strong focus on the impact of framework policy, the literature review focuses more on relevant information for a policy framework, especially which role the policy framework plays on the development and the success of mini- grid. The literature review analysis also aims to identify the kind of policy that can be established and how good each policy measure is functioning. This is necessary to understand why a specific measure should be preferred to another one, and at which stage of the mini-grid development a specific policy measure should be applied.

\section{Methodology}

he methodology used for the study is an analysis of the $\langle$ Titerature related to the topic (table 1).

\section{Results}

\section{Theoretical background}

hen it comes to the development of renewable energy $\langle$ Wtechnologies and its use as a main resource for a mini-grid business, existing policies play a significant role. Researchers differentiate between two main common market mechanisms used for the development of renewable energy: first, the «quota mechanism» or the "quantity-based mechanism» and second, the "price based mechanism» or "feed-in tariff». Both these mechanisms produce a two different systems for a mini-grid business.

\section{Mechanism 1}

$\mathrm{n}$ the case of application of the quota mechanism, the I system is hardly influencing the competition inside the system. The quota mechanism is still a market mechanism since «the price of the energy in this system will be determined by the market». When the quota mechanism is applied, the government or the public authority pre-determines the quantity of renewable energy which should be used for the generation of electricity. It is meant to reach a specific percentage of renewable energy share over the country, whereby the market determines the price of the energy. The quota can be implemented in two ways: first the tendering system and second the green certificate or the renewable energy obligation. An example country where quota mechanism was implemented is the United Kingdom (Asl, 2010). The quota mechanism allows an intensive competition between electricity generation sources. Even though it reduces social costs of renewable energy, it encourages the cheapest renewable energy technology. Moreover, it does not give change to the expansive renewable energy technology developing itself and expand its market proportion. Nonetheless, the application of quota mechanism is a most effective way to reach the aimed share for a certain renewable energy system (Azuela \& Barroso, 2011; e-Parliament, 2009; Fischer \& Preonas, 2010; Menanteau \& Lamy, 2002).

\section{Mechanism 2}

he second common market mechanism used to support the $\langle$ Tdevelopment of the renewable energy is the feed-in tariff 1 mechanism. This mechanism is an influencing system through a technology approach. The feed-in tariff is «[a] renewable energy policy that typically offers: [a] guarantee of payments to project owners for $\mathrm{kWh}$ of renewable electricity produced, [a]ccess to the grid and [s]table, long-term contracts (15-20 years)» (Azuela \& Barroso, 2011; Cory, Karlynn, 2009; eParliament, 2009; Fischer \& Preonas 2010; Menanteau et al., 2002). When this mechanism is applied, the government or the public authority pre-determines the price for electricity generated from renewable energy sources, and the market determines the quantity produced. To make the system functional, through the pre-determined price of electricity from renewable energy sources, all operators are forced to connect their generators to the grid and electricity supply companies are forced to buy electricity from the renewable energy sources (Asl, 2010). 
Table 1

Main findings of the literature review related to mini-grid

\begin{tabular}{|c|c|c|}
\hline Author(s) & Geographic area & Main findings \\
\hline $\begin{array}{l}\text { Dutt, \& MacGill } \\
\qquad(2013)\end{array}$ & Fiji & $\begin{array}{l}\text { Two key factors for the success of hybrid mini-grid: } \\
\text { - reliability: not only a technical issue, but also influenced by the background conditions of } \\
\text { rural areas. Best practices and regulatory guidelines should be shared. The } \\
\text { technology should be good understood and the personal of the mini-grid should } \\
\text { be well trained; } \\
\text { - cost-competitiveness: the reliability strengthen the competitiveness of the cost of } \\
\text { electricity. }\end{array}$ \\
\hline $\begin{array}{l}\text { Van Gevelt, } \\
\quad(2014)\end{array}$ & $\begin{array}{l}47 \text { countries in seven } \\
\text { regions: East Asia and } \\
\text { Pacific, Europe, North } \\
\text { America, Latin America } \\
\text { and the Caribbean, } \\
\text { Middle East and North } \\
\text { Africa, Sub-Saharan } \\
\text { Africa and South Asia }\end{array}$ & $\begin{array}{l}\text { Overview of the academic literature on off-grid energy provision in rural areas and useful } \\
\text { background information for the smart village initiative. }\end{array}$ \\
\hline $\begin{array}{l}\text { Palit, \& Sarangi, } \\
\quad(2014)\end{array}$ & India & $\begin{array}{l}\text { Appropriate support scheme for successful mini-grid should be a mixture of both } \\
\text { 'Participators approach' and 'Top-down approach'. Technical, policy and financing issues } \\
\text { for mini-grid can be dealt at the appropriate intermediary and/or higher level. }\end{array}$ \\
\hline $\begin{array}{l}\text { Foster et al., } \\
(2014)\end{array}$ & Australia & Successful rural electrification projects require supportive institutional frameworks. \\
\hline Remson, (2015) & $\begin{array}{l}\text { Kenya, Ethiopia and } \\
\text { Tanzania }\end{array}$ & $\begin{array}{l}\text { The development of mini-grids offers a great opportunity for development in East Africa. } \\
\text { To use this opportunity a favourable policy environment must be created and the existing } \\
\text { policy and regulatory barriers must be removed. }\end{array}$ \\
\hline $\begin{array}{l}\text { Blum et al., } \\
\quad(2015)\end{array}$ & Laos & $\begin{array}{l}\text { Propose a national technology-specific electrification strategy which aligns the institutional } \\
\text { settings and thereby removes the key barriers to the diffusion of mini-grid. To achieve this } \\
\text { goal two cornerstones are needed: a selection of preferred technologies based on a } \\
\text { 'technology needs assessment' and the establishment of a national body to collect, share, } \\
\text { translate and pass on knowledge related to the selected technology as well as to mediate } \\
\text { and translate between actors from different cultural backgrounds. }\end{array}$ \\
\hline $\begin{array}{l}\text { Manetsgruber } \\
\text { et al. (2015) }\end{array}$ & Developing countries & $\begin{array}{l}\text { Assessment of main risks related to mini-grid and a definition of a methodology to manage } \\
\text { the risks related to mini-grid. }\end{array}$ \\
\hline $\begin{array}{l}\text { Steurer et al. } \\
\quad(2016)\end{array}$ & Sub-Sahara African & $\begin{array}{l}\text { An appropriate way to deal with the main risks related to mini-grid in Sub-Saharan African is } \\
\text { to separate these risks and address each risk to an appropriate risk mitigation institution. }\end{array}$ \\
\hline
\end{tabular}

The guarantee of payment for kWh for electricity generated from a specific renewable energy source - solar PV, or wind, or biogas ... - is determined and guaranteed for a long term period by the authority. The time horizon is usually set by about 20 years which allows a long-term planning for the investors as well as their security in the pay-back of the high investment cost. When it comes to the achievement of a specific target for renewable energy technology, the feed-in tariff is not the most effective mechanism (Azuela \& Barroso, 2011; e-Parliament, 2009; Fischer \& Preonas, 2010; Menanteau et al., 2002).

\section{Findings}

s can be seen, the two approaches create a different $\langle$ A frameworks which may drastically influence the investigated system of a mini-grid business. The impact of the framework, however, might be not direct but through other formal and informal factors related to the type of policy mechanism applied.

Some of the factors related to the policy mechanisms are displayed in fig. 1.

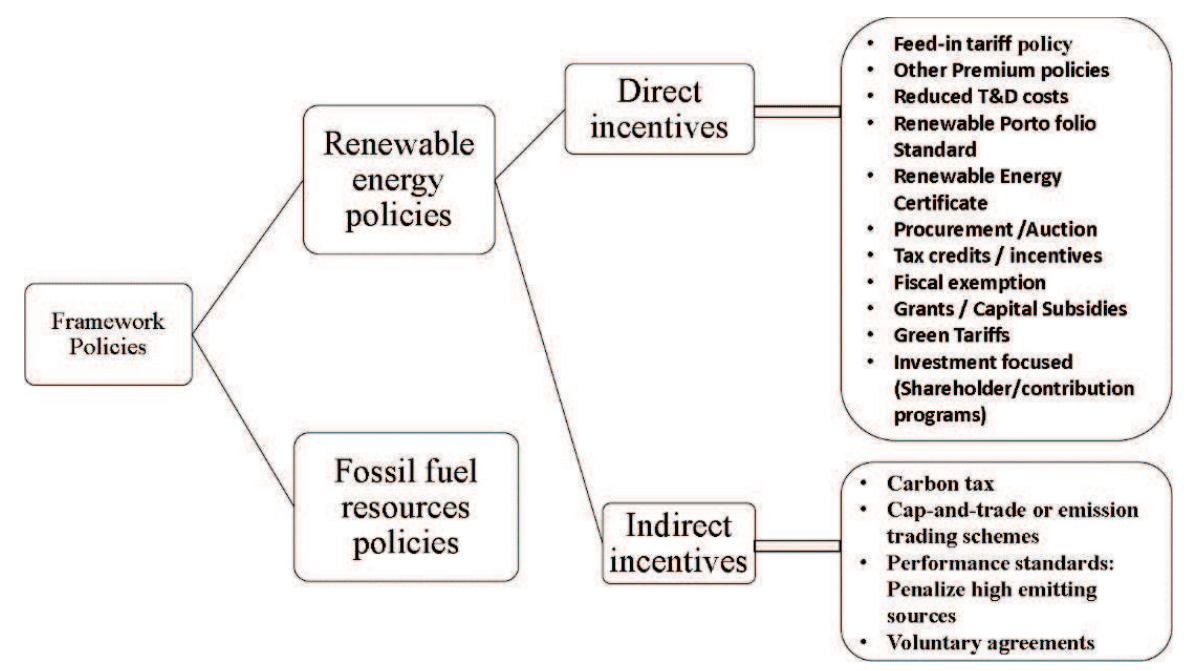

Fig. 1. Analytic Diagram of Framework Policies 
In order to define such impact and see the path the system is going to follow in the future, as well as to predict the pace of a system development, a holistic, systemic approach is proposed. One of the appropriate solutions for the investigation of the minigrid business would be a systems theory following the method proposed by Vester.

If one follows the instructions by Frederic Vester (Vester, 2002) he or she has to make a literature and case analysis in order to define a list of «nodes» or interrelated factors which are relevant for the investigated system. Later on, the factors are connected through a series of relations and specific values for these relationships are prescribed. This first analysis helps to determine the factors related to the framework policies of mini-grid.

The analysis of the above relate literature review reveals the following concerning the deployment of policy for an effective development of mini-grid.

Feed-in tariff policy: to be effective a feed-in tariff policy should guaranty access to the grid. Since many developing countries, especially countries in Sub-Saharan Africa have a less developed grid, it is difficult and almost impossible for these countries to guaranty an access to the grid. Therefore feed in tariff policy does not appear as an appropriate policy instrument to increase electricity access rate in these countries.

Specific mini-grid policy: without a specific mini-grid policy it is almost impossible to invest in mini-grid. The investors in mini-grid are doing business and need at least a minimum warranty that they can make a profit. This implies the deliverance of authorization or licenses to deploy their business and even more support from the electricity authority. This warranty of profit for the private investors could only be achieved through effective political support. This follows a well-known economic principle: "countries that have achieved sustained economic growth have used a range of supportive policy intervention» (United Nations, 2012).

Moreover, to be effective a policy intervention need to be adapted to the local and national context. Since most of the developing countries have a huge need to increase their electrification access rate and at the same time do not have enough technical means to produce technological components for electricity generation, effective supportive policy intervention should go through several phases:

First phase: decreasing of import taxes for electricity technology and incentive for training related to electricity technology. During this phase, the policy intervention should facilitate the access to electricity technology through a strong reduction of import taxes for this technology. This is necessary because at this phase the access to electricity technology can only be achieved through an import. High import taxes are only a barrier to electricity access. To open access to the second phase it is required during this phase to establish training programs relate to the development of electricity technology.

Second phase: establishing a local manufacturing for the production of electricity technology components. This phase can only be reached when the second part of the first phase has been well completed.

Third phase: during this phase, the local manufacturing for the production of electricity technology is very young and not strong enough to compete with the international manufacturing. The manufacturing then needs to be protected by the local authorities.

\section{Conclusions}

his paper focuses on the most important aspects of the Tinnovation management in the sphere of decentralized 1 electrification through the development of mini-grid and renewable energy technology. A short literature review revealed the following important aspect to be approached in future research:

- the identification of other factors categories which are influencing the deployment of mini-grid;

- the determination of the set of system loops related to minigrid;

- the definition of a holistic and systemic approach to analyze the influencing factors of mini-grid.

Accordingly, the next steps for the future research are to:

(i) develop a system factors influencing mini-grids;

(ii) develop an interrelation matrix as proposed by Vester (2002);

(iii) apply a three-phase-algorithm including taxation, local manufacturing creation and local manufacturing protection;

(iv) calculate a set of active and passive factors related to minigrids;

(v) run a simulation model in order to investigate systemic interrelations energy sector and, thus, provide managers and local authorities with an instrument for the market regulation.

\section{References}

Azuela, Gabriela Elizando, \& Barroso, Luiz Augusto. (2011). Design and Performance of Policy Instruments to Promote the Development of Renewable Energy: Emerging Experience in Selected Developing Countries. Retrieved October 10, 2016, from

http://siteresources.worldbank.org/EXTENERGY2/Resourc es/DiscPaper22.pdf.

Blum, Nicola U., Bening, Catherina Rebecca, \& Schmidt, Tobias S. (2015). An analysis of remote electric mini-grids in Laos using the Technological Innovation Systems approach EconBiz. Retrieved October 10, 2016, from https://www.econbiz.de/Record/an-analysis-of-remoteelectric-mini-grids-in-laos-using-the-technologicalinnovation-systems-approach-blum-nicola/10011474622.

Cory, Karlynn. (2009). Feed-in Tariffs: Best Practices and Applications in the United States. Retrieved October 10, 2016, from http://www1.eere.energy.gov/wip/ solutioncenter/pdfs/tap_webinar_20091028.pdf.

Debajit Palit, \& Gopal K. Sarangi. (2014). Renewable Energy based Mini-grids for Enhancing electricity Access: Experiences and Lessons from India. Retrieved October 10, 2016, from https://www.dmu.ac.uk/documents/technologydocuments/research-faculties/oasys/projectoutputs/conference-papers/cp25-palit-and-sarangi-s-104icue2014-211-o.pdf.

Economic Consulting Associates. (2014). Project Design Study on the Renewable Energy Development for Off-Grid Power Supply in Rural Regions of Kenya. Retrieved October 11, 2016, from http://www.renewableenergy.go.ke/asset_upl ds/files/ECA\%20Kenya\%20Minigrids\%2oReport\%20\%2orevised\%2ofinal(1).pdf. 
e-Parliament. (2009, September). The Role of Feed-in Tariff Policy in Renewable Energy Development in Developing Countries: A Toolkit for Parliamentarians. Retrieved August $\quad$ 11, 2016, from http://www.eparl.net/eparliament/pdf/ogo911FITDevCountries.pdf.

Fischer, Carolyn, \& Preonas, Louis. (2010). Combining policies for renewable energy: is the whole less than the sum of its parts? Retrieved October 10, 2016, from https://core.ac.uk /download/pdf/9307514.pdf?repositoryld=153.

Franz, Michael, Peterschmidt, Nico, Rohrer, Michael, \& Kondev, Bozhil. (2014). Mini-grid Policy Toolkit: Policy and Business Frameworks for Successful Mini-grid Roll-outs. Retrieved October 11, 2016, from http://www.ren21.net/Portals/o/do cuments/Resources/MGT/MinigridPolicyToolkit_Sep2014_ EN.pdf.

Hellpap, Carsten. (2013). How can international cooperation contribute to Sustainable Energy for All. Retrieved October 11, 2016, from https://sustainabledevelopment.un .org/content/documents/4713hellpap.pdf.

Manetsgruber, David, Wagemann, Bernard, Bozhil Kondev, \& Katrin Dziergwa. (2015). Risk Management for mini-grids: a new approach to guide mini-grid deployment. Retrieved October 10, 2016, from https://www.ruralelec.org/sites/de fault/files/risk management for minigrids_2015_final_web_o.pdf.

Menanteau, P., Finon, D., \& Lamy, M.-L. (2002). Prices versus quantities: choosing policies for promoting the development of renewable energy. Retrieved August 11, 2016, from http://seg.fsu.edu/Library/prices\%20vs\%20quan tities.pdf.

Peterson, Paul E. (1981). City Limits. Retrieved October 11, 2016, from http://publius.oxfordjournals.org/content/13 /3/106.full.pdf.

Ranjit Deshmukh, Juan Pablo Carvallo, \& Ashin Gambhir. (2013). Sustainable development of renewable energy mini-grids for energy access: A framework for policy design. Retrieved

October 10, 2016, from http://www.cleanenergyministeria
I.org/Portals/2/pdfs/Sustainable Development of Renew able_Energy_Mini-grids_for_Energy_Access.pdf.

Remson, John. (2015). Rural Energy Development: Are Mini-grids the solution to East Africa's Energy Crisis. Retrieved October 10, 2016, from http://academicworks.cuny.edu/cg i/viewcontent.cgi?article $=1358 \&$ context $=c c$ _etds_theses.

Steurer, Elmar, Manetsgruber, David, \& Jouégo, Esther Prudence. (2016). Risk Clustering as a Finance Concept for Rural Electrification in Sub-Saharan Africa to Attract International Private Investors. Retrieved October 10, 2016, from http://www.sciencedirect.com/science/article/ pii/S1876610216305951

United Nations. (2012). Macroeconomic stability, inclusive growth and employment. Retrieved October 10, 2016, from http:// www.un.org/millenniumgoals/pdf/Think\%2oPieces/12_mac roeconomics.pdf.

Vahid Behzadi Asl. (2010). Promotion of market share for renewable energy: which mechanism can promote market share for renewable energy effectively. Retrieved June 27, 2016, from https://www.google.de/url?sa=t\&rct=j $\& q=\& e s r c=s \&$ source $=$ web $\& c d=1 \& c a d=r j a \& u a c t=8 \& v e d=0$ ahUKEwiyhNGapsjNAhUsG50KHUZFAzYQFggeMAA\&url= http\%3A\%2F\%2Fwww.dundee.ac.uk\%2Fcepmlp\%2Fgateway \%2Ffiles.php\%3Ffile\%3Dcepmlp car13 73 983719504.pdf\& usg=AFQjCNHyn5AgQZp_Xh7zrnfNJbgQFskpDw\&bvm=b v.125596728,d.bGs.

Van Der Plas, Robert, \& Pigaht, Maurice. (2013). Mini-Grids: A public-private balancing act: Political, economic and organisational lessons from Namibia, Senegal and Rwanda. Retrieved October 11, 2016, from https://www.gi z.de/fachexpertise/downloads/2013-en-pigaht-pepinformationsworshop.pdf.

Van Gevelt, Terry. (2014). Off-grid energy provision in rural areas: a review of the academic literature. Retrieved October 10, 2016, from http://e4sv.org/wp-content/uploads/2014/02 /Off-grid-energy-literature-review-Terry-van-Gevelt-1.pdf.

Vester, F. (2002). Die Kunst vernetzt zu denken: Ideen und Werkzeuge für einen neuen Umgang mit Komplexität Ein Bericht an den Club of Rome. dtv Verlagsgesellschaft. 